\title{
Endosporoideus gen. nov., a mitosporic fungus on Phoenix hanceana
}

Wai Hong $\mathrm{Ho}^{1}$

Yanna

Kevin D. Hyde

Teik Khiang Goh

Centre for Research in Fungal Diversity, Department of Ecology $\mathcal{G}$ Biodiversity, University of Hong Kong, Pokfulam Road, Hong Kong

Abstract: Endosporoideus pedicellata gen. et sp. nov. is described and illustrated from decaying petioles of Phoenix hanceana collected from grassland in Tai Mo Shan, Hong Kong. The genus is unique in producing solitary, phragmosporous conidia. The conidia comprise a brown to dark brown inner-wall layer and thick, hyaline outer-wall layer and are produced holoblastically from determinate conidiogenous cells on micronematous, mononematous conidiophores. Cells of conidia may disarticulate at the septa. Rep-

Accepted for publication 24 Aug 2004.

${ }^{1}$ Corresponding author. E-mail: whhob@hkucc.hku.hk resentative steps in conidiogenesis of $E$. pedicellata are illustrated with light micrographs, and details of the conidiogenous events are interpreted schematically.

Key words: palmicolous fungi, saprobes, systematics

\section{INTRODUCTION}

In a continuing study of palm fungi in the tropics (Yanna et al 1997, 1998a, b, 1999, 2000a, b, 2002; Hyde et al 2002), an undescribed dematiaceous mitosporic fungus was found on decaying fronds of Phoenix hanceana Naud., growing in grassland mountain areas in Hong Kong. The fungus is reminiscent of genera such as Janetia, Pithomyces and Trichocladium (Carmichael et al 1980, Goh and Hyde 1996) in producing micronematous, mononematous conidiophores, and solitary, holoblastic, dematiaceous, phragmosporous conidia.

The fungus is unique in producing conidia with an

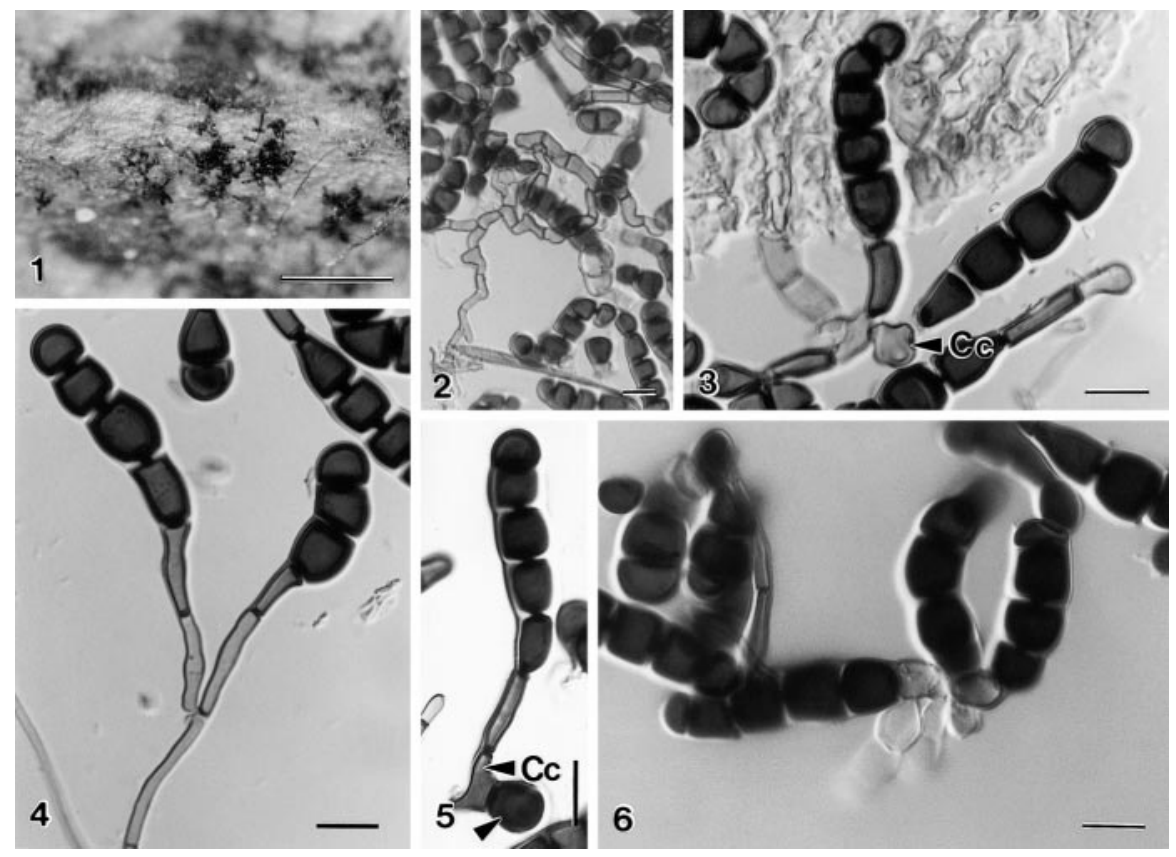

FIGS. 1-6. Light micrographs of E. pedicellata (from holotype). Cc = conidiogenous cells. 1. Colonies on natural substratum. 2. Hyphae and conidia. 3, 4. Conidiogenous cells and conidia. 5. Conidiogenous cell with a mature conidium and a developing conidium (arrowhead). 6. Conidia in fascicles. Note the immature conidia produced from the conidiogenous cell (arrowhead). Scale bars: $1=500 \mu \mathrm{m} ; 2=25 \mu \mathrm{m} ; 3-6=10 \mu \mathrm{m}$. 

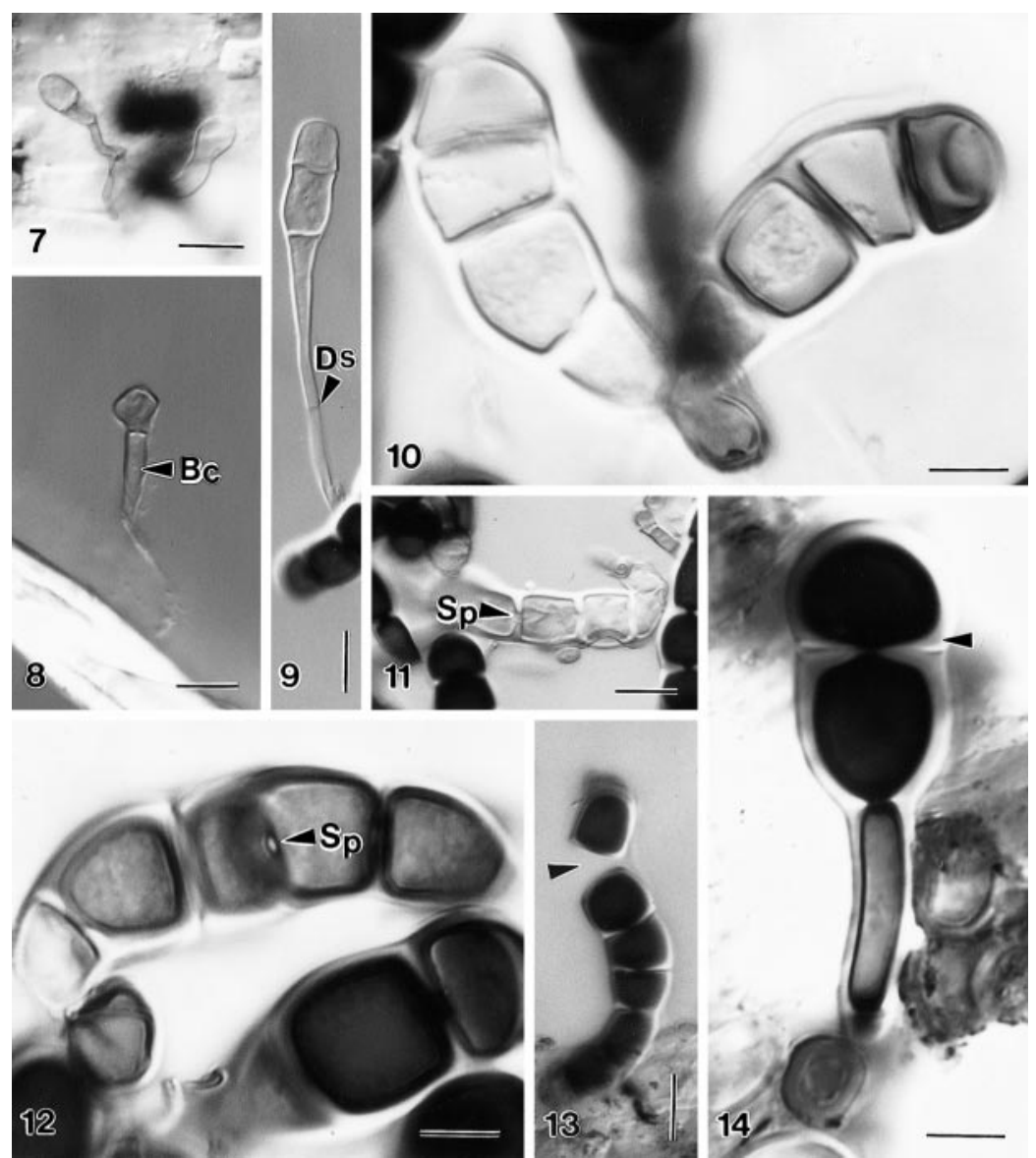

Figs. 7-14. Light micrographs of representative steps in the conidiogenesis of E. pedicellata. Bc $=$ conidial basal cell, Ds $=$ conidial delimiting septum, $\mathrm{Sp}=$ septal pore. 7 . Immature conidia on natural substratum. 8 . Immature conidium with a swollen conidial cell and a basal cell. 9. Immature conidium with two swollen conidial cells and a basal cell. Note the delimiting septum. 10. Immature conidia with thickened, hyaline wall and septa. 11. An immature conidium with a septal pore in side view. 12. Conidial septal pore viewed from above. 13. Mature conidium with cells disarticulate at the septum (arrowhead). 14. Mature conidium with two swollen conidial cells and a cylindrical basal cell. Note the thick hyaline conidial wall and septa (arrowhead). Scale bar: 7-9, 11, $13=10 \mu \mathrm{m} ; 10,12,14=5 \mu \mathrm{m}$.

extensively thick, hyaline outer-wall layer and brown inner-wall layer. The conidia appear to resemble isthmospores that are formed endogenously in thick sheaths, but they are in fact phragmosporous. Cryoscanning electron microscopy was used to confirm these observations. A new genus, Endosporoideus, is introduced and a new species, E. pedicellata, is described to accommodate the unidentified fungus. Representative steps in conidiogenesis of E. pedicellata are illustrated using interference contrast microscopy, and the interpreted conidiogenesis events are illustrated with schematic diagrams.

\section{METHODS}

Decaying fronds of Phoenix hanceana were collected in Hong Kong. Fungi growing on the substrata were examined with light and cryoscanning electron microscopy as described in Ho et al (1998). All measurements provided in this paper were made from material mounted in water. Material has been deposited in the herbarium of The Centre for Research in Fungal Diversity, University of Hong Kong (HKU $[\mathrm{M}]$ ).

TAXONOMY

Endosporoideus W.H. Ho, Yanna, K.D. Hyde et Goh, gen. nov.

Coloniae in substrato naturali effusae, dematiaceae. Mycelium partim in substrata immersum vel partim superficiale, ex hyphis ramosis, septatis, pallide brunneis, laevibus, tenuitunicatae, flexuosae compositum. Stromata, setae et hyphopodia absentia. Conidiophora micronemata, mononemata. Cellulae conidiogenae terminales vel intercalares, polyblasticae, persistentes, dematiaceae, laevibus. Conidia holoblastica, solitaria, multi-euseptata, clavata vel cylindricaclavata, flexuosa, dematiaceae; cellula basilare angustum, productum; tunica et septa hyalina, tenuitunicata cum immaturitas, crassitunicatae cum maturesca, endosporium 

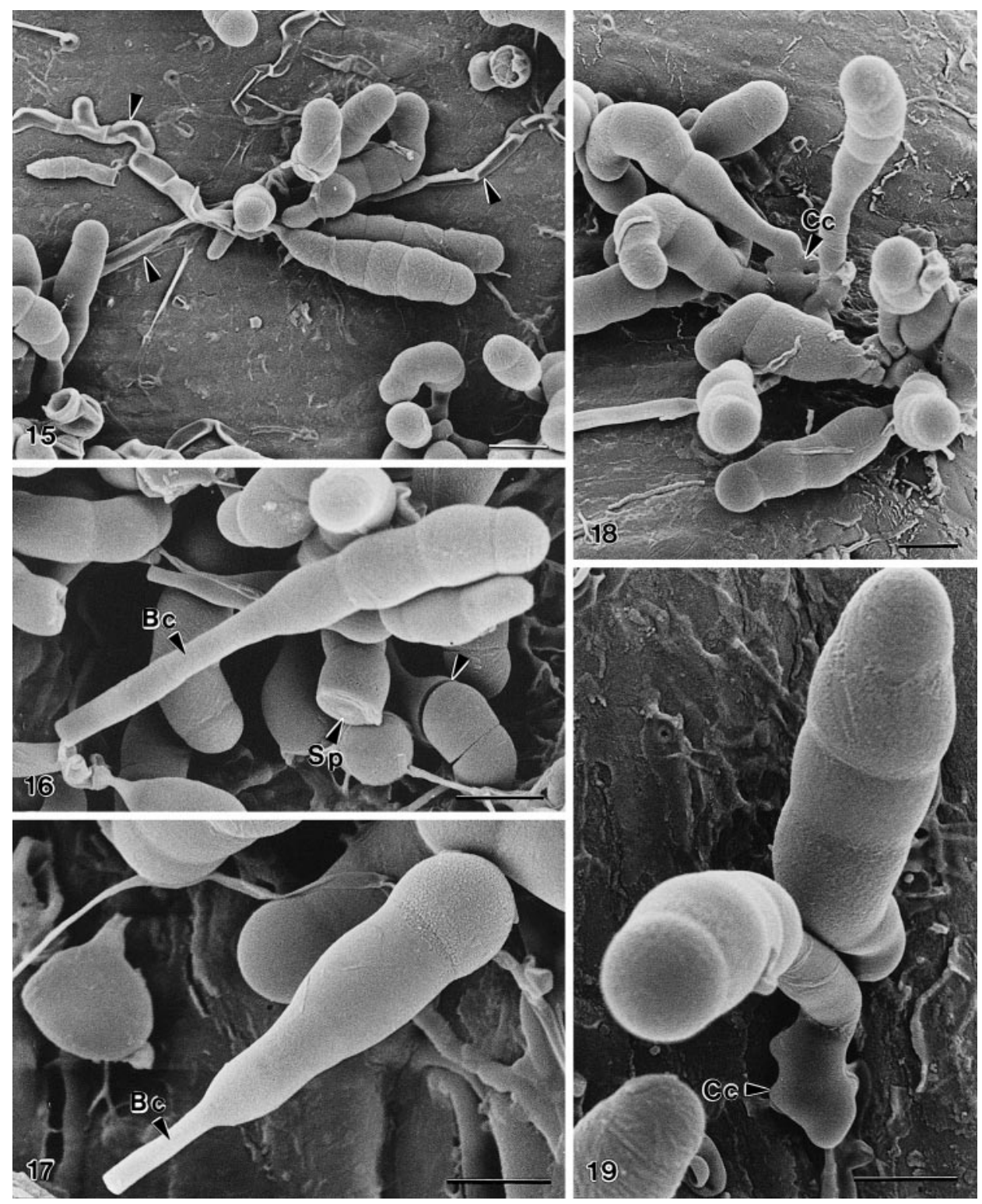

Figs. 15-19. Scanning electron micrographs of E. pedicellata (from holotype). Bc = basal cells, Cc = conidiogenous cells, $\mathrm{Sp}=$ conidial septal pore. 15. Colony on natural substratum illustrating fascicles of conidia and superficial hyphae (arrowheads). 16, 17. Phragmoid conidia. Note the elongated basal cells, disarticulation of conidial cells (arrowhead) and the exposed conidial septal pore. 18. Fascicles of conidia produced from lobed conidiogenous cells. 19. Higher magnification of the lobed conidiogenous cell at the base of the conidia. Scale bars: $15,16=10 \mu \mathrm{m} ; 17,18=5 \mu \mathrm{m} ; 19=15 \mu \mathrm{m}$.

brunneis cum maturitas, similis sum dematiaceae isthmospora. Conidiorum secessio schizolytica.

Species typica Endosporoideus pedicellata W.H. Ho, Yanna, K.D. Hyde \& Goh.

Colonies on natural substratum effuse, dematiaceous. Mycelium partly immersed and partly superficial, comprising branched, septate, pale brown, smooth, thin-walled, flexuous or interwoven hyphae. Stromata, setae and hyphopodia absent. Conidiophores micronematous, mononematous. Conidiogenous cells terminal or intercalary, polyblastic, persistent, dematiaceous, smooth-walled, proliferating; conidiogenous loci appearing successively at the same level without elongation of the conidiogenous cells, giving rise to a cluster of conidia. Conidia holoblastic, solitary, transversely multi-euseptate, with prominent central septal pores, clavate or cylindrical-clavate, flexuous, dematiaceous, broadly rounded at the apex, truncate at the base, frequently with a narrow, elongated basal cell; conidial walls and septa hyaline, thin when immature, thickening during maturation, the inner wall becoming brown at maturity, resembling dematiaceous endogenous isthmospores surrounded with thick hyaline membranes; conidial cells occasionally 


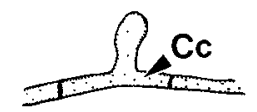

20

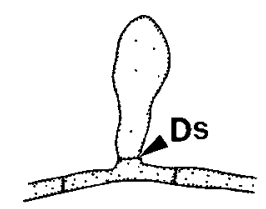

21

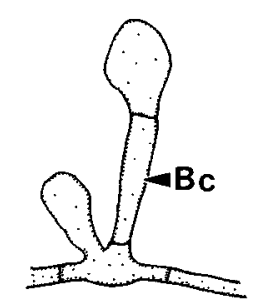

22

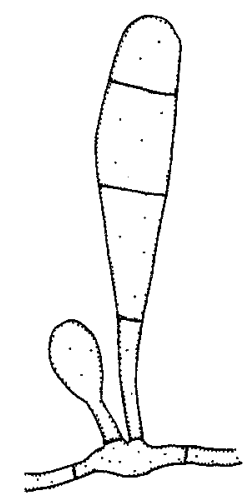

23

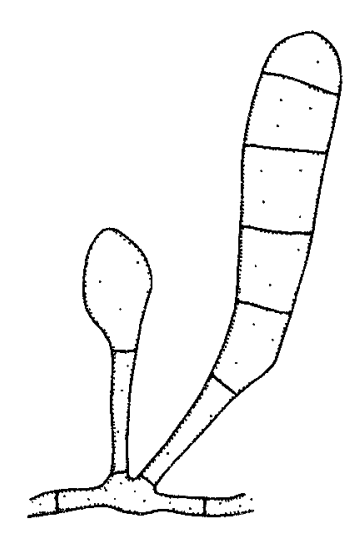

24

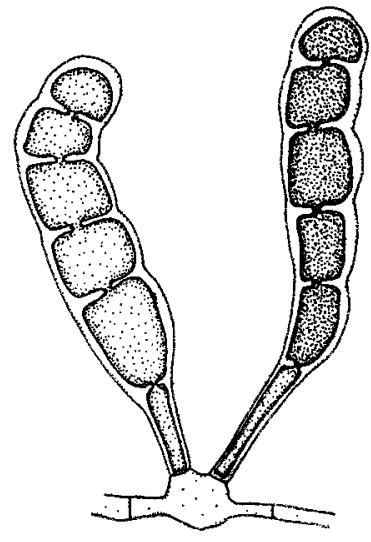

27

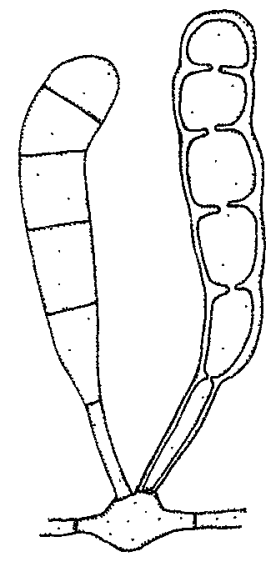

25

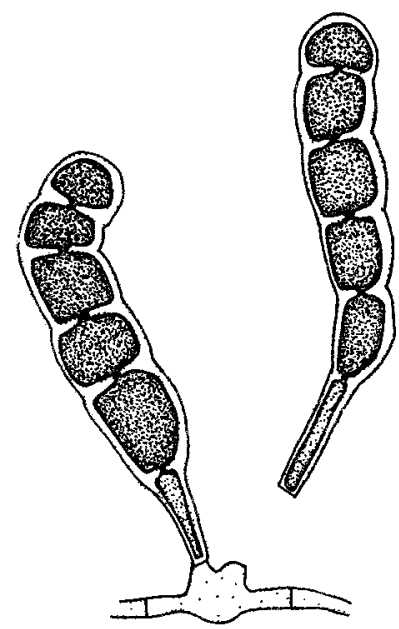

28

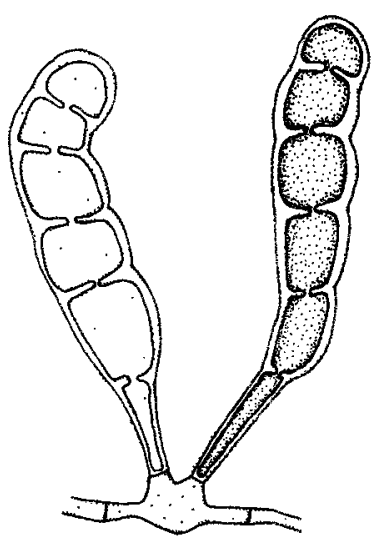

26

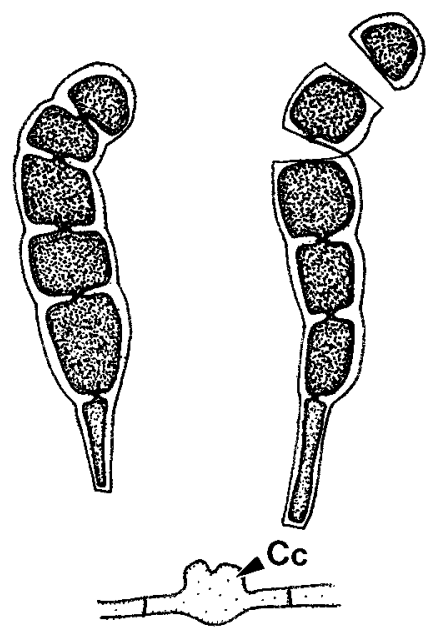

29

Figs. 20-29. Diagrammatic representation of conidial development and dehiscence in E. pedicellata. Bc = basal cell, Cc $=$ conidiogenous cell, Ds = delimiting septum. 20. Holoblastic ontogeny of the first conidium. 21. Conidial delimitation. 22. Formation of the first transverse conidial septum in the first conidium, and ontogeny of the second conidium. 23, 24. Conidial maturation with apical wall-building, to form several transverse septa as the conidia elongate. 25. Conidial maturation with diffuse wall-building in the first conidium, to form thick conidial wall and septa. 26, 27. Deposition of an inner brown to dark brown wall layer. 28. Schizolytic conidial secession of the first conidium. 29. Schizolytic conidial secession of the second conidium and cells disarticulate at the septa in the first conidium. Note the lobed appearance of the conidiogenous cells after conidial secessions. Scale bar $=10 \mu \mathrm{m}$. 
TABLE I. Diagnostic characteristics of Endosporoideus and similar genera

\begin{tabular}{|c|c|c|c|c|}
\hline & $\begin{array}{l}\text { Endosporoideus } \\
\text { W.H. Ho, Yanna, } \\
\text { K.D. Hyde \& Goh }\end{array}$ & $\begin{array}{l}\text { Antennathula } \\
\text { Fr. ex. F. Strauss } \\
\quad(\text { Ellis 1971) }\end{array}$ & $\begin{array}{l}\text { Henicospora } \\
\text { P.M. Kirk \& } \\
\text { B. Sutton (1980) }\end{array}$ & $\begin{array}{c}\text { Janetia } \\
\text { M.B. Ellis } \\
\text { (Goh and Hyde 1996) }\end{array}$ \\
\hline \multirow[t]{2}{*}{ Conidiophores } & Micronematous & Micronematous & $\begin{array}{l}\text { Micro- or semi- } \\
\text { macronematous }\end{array}$ & Micronematous \\
\hline & Mononematous & Mononematous & Mononematous & Mononematous \\
\hline \multirow{4}{*}{$\begin{array}{l}\text { Conidiogenous } \\
\text { cells }\end{array}$} & Integrated & Integrated & Integrated & Integrated \\
\hline & Holoblastic & Holoblastic & Holoblastic & Holoblastic \\
\hline & Polyblastic & Monoblastic & $\begin{array}{l}\text { Mono- or } \\
\text { polyblastic }\end{array}$ & Polyblastic \\
\hline & $\begin{array}{l}\text { Cylindrical when } \\
\text { unilocal, lobed } \\
\text { when multilocal }\end{array}$ & $\begin{array}{l}\text { Cylindrical or } \\
\text { doliform }\end{array}$ & Cylindrical & Denticulate \\
\hline \multirow[t]{4}{*}{ Conidia } & $\begin{array}{l}\text { Solitary, mostly } \\
\text { in fascicles }\end{array}$ & Solitary & Solitary & Solitary \\
\hline & Phragmosporous & Phragmosporous & Phragmosporous & Phragmosporous \\
\hline & Euseptate & Euseptate & Euseptate & $\begin{array}{l}\text { Euseptate, with } \\
\text { or without } \\
\text { distoseptata }\end{array}$ \\
\hline & Schizolytic & Schizolytic & Rhexolytic & Schizolytic \\
\hline Chlamydospores & Absent & Absent & Absent & Absent \\
\hline Teleomorph & Unknown & $\begin{array}{l}\text { Euantennaria } \\
\text { Speg. }\end{array}$ & Unknown & Unknown \\
\hline
\end{tabular}

disarticulate at the septa. Conidia formed holoblastically by apical wall building, followed by delimitation by a transverse septum, and schizolytic secession; conidiogenous cells proliferate without elongation, forming conidia successively from other conidiogenous loci; conidia mature by (i) apical wall-building, to form several transverse septa as the conidia elongate, (ii) diffuse wall-building, to form thick conidial wall and septa, and subsequently (iii) deposition of an inner brown to dark brown wall layer.

Etymology. Endosporoideus refers to the endosporelike conidia that comprises a hyaline outer wall layer and brown inner wall layer.

Endosporoideus pedicellata W.H. Ho, Yanna, K.D. Hyde et Goh, sp. nov. FIGS. 1-19

Coloniae in substrato naturali effusae, fuscus. Mycelium partim in substrato immersum vel partim superficiale, ex hyphis ca. $12 \mu \mathrm{m}$ lata, ramosis, septatis, pallide brunneis, laevibus, tenuitunicatae, flexuosae compositum. Cellulae conidiogenae pallide brunneis vel brunneis, initio cylindrica, tum lobatus, laevibus. Conidia (16-)24-74 × 10-12 $\mu \mathrm{m}$, phragmospora, solitaria, 1-7-euseptata, clavata vel cylindrica-clavata, recta vel flexuosa, brunneis vel fuscus; pori septum centrale, conspica, 2-3 $\mu \mathrm{m}$ lata, 1.5-2 $\mu \mathrm{m}$ longa; cellula basilare angustum, productum; tunica et septa hyalina, cum immaturitas tenuitunicata, cum maturesca crassitunicatae, usque ca. $1 \mu \mathrm{m}$ crassa, cum maturitas endosporium brunneis vel fuscus, similis sum dematiaceae isthmospora. Conidiorum secessio schizolytica.

Colonies on natural substratum effuse, dark brown (FIG. 1). Mycelium partly immersed and partly superficial, comprising branched, septate, pale brown, smooth, thin-walled, flexuous or interwoven hyphae, ca. $12 \mu \mathrm{m}$ wide (FIG. 2). Conidiogenous cells pale brown to brown, cylindrical initially, becoming lobed after proliferation, smooth-walled (FIGS. 3-6); conidiogenous loci appearing successively at the same level without elongation of the conidiogenous cells, giving rise to a cluster of conidia (FIGs. 3, 5, 6). Conidia (16-) 24-74 $\times 10-12 \mu \mathrm{m}(\bar{x}=58.3 \times 11.5 \mu \mathrm{m}, \mathrm{n}=$ 25), phragmosporous, solitary, 1-7-euseptate, with prominent central septal pores, viewed as channels in side view, 2-3 $\mu \mathrm{m}$ wide, 1.5-2 $\mu \mathrm{m}$ long, clavate or cylindrical-clavate, straight or flexuous, brown to dark brown, broadly rounded at the apex, truncate at the base, occasionally with a narrow, elongate basal cell (Figs. 3-6, 10-12, 14); distal conidial cells $6-8 \times$ 5-9 $\mu \mathrm{m}(\bar{x}=7.5 \times 7.1 \mu \mathrm{m}, \mathrm{n}=25)$; central conidial cells $8-12 \times 7-10 \mu \mathrm{m}(\bar{x}=10 \times 9 \mu \mathrm{m}, \mathrm{n}=25)$; proximal conidial cells elongate, cylindrical, 7-34 $\times 2-$ $6 \mu \mathrm{m}(\bar{x}=17.3 \times 3.5 \mu \mathrm{m}, \mathrm{n}=25)$; conidial walls 
TABLE I. Extended

\begin{tabular}{|c|c|c|c|}
\hline $\begin{array}{l}\text { Pithomyces } \\
\text { Berk. \& Broome } \\
\text { (Ellis 1971) }\end{array}$ & $\begin{array}{c}\text { Polyschema } \\
\text { H.P. Upadhyay } \\
\text { (Ellis 1976) }\end{array}$ & $\begin{array}{c}\text { Sanjuanomyces } \\
\text { R.F. Castañeda \& } \\
\text { W.B. Kendr (1991) }\end{array}$ & $\begin{array}{l}\text { Trichocladium } \\
\text { Harz (Goh and } \\
\text { Hyde 1999) }\end{array}$ \\
\hline $\begin{array}{l}\text { Micro- or semi- } \\
\text { macronematous }\end{array}$ & $\begin{array}{l}\text { Micro- or semi- } \\
\text { macronematous }\end{array}$ & Micronematous & $\begin{array}{l}\text { Micro- or semi- } \\
\text { macronematous }\end{array}$ \\
\hline Mononematous & Mononematous & Mononematous & Mononematous \\
\hline Integrated & $\begin{array}{l}\text { Integrated or } \\
\text { discrete }\end{array}$ & Integrated & Integrated \\
\hline Holoblastic & $\begin{array}{l}\text { Enteroblastic } \\
\text { tretic }\end{array}$ & $\begin{array}{l}\text { Enteroblastic } \\
\text { tretic }\end{array}$ & Holoblastic \\
\hline $\begin{array}{l}\text { Mono- or } \\
\text { polyblastic }\end{array}$ & $\begin{array}{l}\text { Mono- or } \\
\text { polytretic }\end{array}$ & Monotretic & $\begin{array}{l}\text { Mono- or } \\
\text { polyblastic }\end{array}$ \\
\hline $\begin{array}{l}\text { Cylindrical, } \\
\text { denticulate }\end{array}$ & $\begin{array}{l}\text { Spherical or } \\
\text { subspherical }\end{array}$ & Cylindrical & $\begin{array}{l}\text { Pyriform to } \\
\text { clavate }\end{array}$ \\
\hline Solitary & Solitary & Solitary & Solitary \\
\hline $\begin{array}{l}\text { Amero-, didymo-, } \\
\text { phragomo- or } \\
\text { dictyosporous }\end{array}$ & $\begin{array}{l}\text { Didymo- or } \\
\text { phragmosporous }\end{array}$ & Phragmosporous & $\begin{array}{l}\text { Didymo- or } \\
\text { phragmosporous }\end{array}$ \\
\hline Euseptate & Euseptate & Euseptate & Euseptate \\
\hline Rhexolytic & Schizolytic & Schizolytic & Schizolytic \\
\hline Absent & $\begin{array}{c}\text { Sometimes } \\
\text { present }\end{array}$ & Absent & Absent \\
\hline $\begin{array}{l}\text { Leptosphaerulina } \\
\text { McAlpine }\end{array}$ & Unknown & Unknown & Unknown \\
\hline
\end{tabular}

and septa hyaline, thin when immature, thickening during maturation, up to ca. $1 \mu \mathrm{m}$ thick, and the inner wall becoming brown to dark brown at maturity, resembling dematiaceous endogenous isthmospores surrounded by thick hyaline membranes (FIGS. $7-11,14)$. The conidia secede by schizolysis, and occasionally the individual conidial cells may disarticulate at the septa (FIG. 13).

HOLOTYPE. HONG KONG. New Territories, Tai Mo Shan, Twisk, on dead petiole of Phoenix hanceana Naud. (Arecaceae), 21 Feb. 1998, Yanna YAN237 (HKU[M] 10066).

Teleomorph. unknown.

Known distribution. Hong Kong.

Etymology. pedicellata refers to the elongate base of the conidia.

Cryo-scanning electron microscopy.-Superficial hyphae were smooth-walled, flexuous or interwoven (FIG. 15). Conidia were produced in loose fascicles from lobed conidiogenous cells (FIGS. 18, 19), and the conidia seceded schizolytically, with a flat base (FIGS. 16, 17). Conidia were constricted at the septa and sometimes disarticulated at the septa. The central septal pores were visible when the conidial fragments were viewed at an angle (FIG. 16). A mucilaginous sheath or membrane surrounding conidia was not observed (FIGS. 16-19).

\section{DISCUSSION}

Conidiogenesis of Endosporoideus.-This sequence of conidium development in E. pedicellata was observed: (i) holoblastic conidial ontogeny (FIG. 20); (ii) delimitation of new conidium by a transverse septum (FIG. 21); (iii) proliferation of conidiogenous cell and a new conidium forms from a second conidiogenous locus at the same level (FIG. 22); (iv) maturation by (a) apical wall-building with several transverse septa forming as the conidium elongates (FIGs. 23, 24), (b) diffuse wall-building forming thick conidial wall and septa (FIG. 25), and subsequently by (c) deposition of an inner brown to dark brown wall layer (FIGs. 26, 27); (v) schizolytic conidium secession (FIG. 28); (vi) frequent disarticulation of cells of conidia at the septa (FIG. 29). The conidiogenous events of Endosporoideus are similar to those of Janetia in the mode of proliferation. Both genera form conidiogenous loci successively at the same level without elongation of the conidiogenous cells (Goh and Hyde 1996). 
Another collection.-Our collection is similar to Matsushima's MFC3377 as described in Matsushima (1975, p 167, entry 575, plate 365, figs. 1, 2) on dead stems of Miscanthus sinensis Anderss. in Japan. In MFC3377, conidia (or "fertile hyphae" in Matsushima 1975) are in loose fascicles, cylindrical, straight to curved, $40-100 \times 8-11 \mu \mathrm{m}$; the conidial cells (or "conidia" in Matsushima 1975) are rectangular, 7-13 $\times$ 6-8 $\mu \mathrm{m}$, thick-walled, black (Matsushima 1975). The morphological characters of both collections are similar. We unsuccessfully requested loan of MFC3377.

Comparison of Endosporoideus with similar genera.Endosporoideus is morphologically most similar to Trichocladium, whose species produce solitary, oval to clavate, euseptate, pigmented phragmosporous conidia from micronematous, mononematous conidiophores in effuse colonies. Trichocladium recently was reviewed by Goh and Hyde (1999) who accepted 18 species. Trichocladium melhae since has been described from marine habitat (Jones et al 2001). Trichocladium differs from Endosporoideus mainly in producing mid- to dark brown conidia that lack a thick, hyaline outer-wall layer and never assemble in fascicles. The thick hyaline outer wall layer in the conidia of Endosporoideus is unique among mitosporic fungi, to our knowledge.

Endosporoideus also resembles Janetia in producing solitary, clavate to cylindrical-clavate phragmosporous conidia from micronematous, mononematous conidiophores in effuse colonies. However, Janetia differs from Endosporoideus mainly in producing brown euseptate conidia, with or without distosepta, on denticulate, densely pigmented conidiogenous cells.

Other genera that are characterized by solitary phragmosporous conidia produced from micronematous conidiophores in effuse colonies include $\mathrm{An}$ tennatula, Henicospora, Janetia, Pithomyces, Polyschema and Sanjuanomyces (Ellis 1971, 1976; Sutton 1980; Rao and de Hoog 1986; Castañeda Ruiz and Kendrick 1990a, b, 1991; Goh and Hyde 1996). Endosporoideus is unique because the pigmented conidia have a thick, hyaline outer-wall layer. The important morphological characters of Endosporoideus and the above seven genera, including Trichocladium, are compared (TABLE I).

Endosporoideus is comparable to genera such as $A n$ nellodentimyces Matsush. and Arthrocladium Papendorf, which are characterized by the production of clusters of dematiaceous, phragmosporous conidia on micronematous conidiophores (Carmichael et a1 1980, Matsushima 1985). These genera differ from Endosporoideus in producing clusters of conidia by sympodial or percurrent proliferation, which results in elongation of the conidiogenous cells. Endosporoideus also is comparable to genera such as Cirrenalia Meyers \& R.T. Moore and Curculiospora Arnaud (Carmichael et a1 1980, Goos et al 1985). Cirrenalia and Curculiospora, however, differ from Endosporoideus because the conidiogenous cells are unilocal and the conidia are helical.

Conidial wall and septa in Endosporoideus.-Matsushima (1975) described the ontogeny of the conidia of MFC3377 as endogenous. In E. pedicellata, the conidia are evidently hologenous. We have illustrated that the conidia are initially hyaline and thin-walled, later becoming thick-walled. At maturity a brown layer is formed beneath the thick, hyaline wall layer. It is thus evident that the conidia are phragmosporous, with a thick hyaline outer-wall layer. The brown conidial cells with a thick, hyaline outer-wall layer in Endosporoideus are unique among mitosporic fungi.

\section{LITERATURE CITED}

Carmichael JW, Kendrick WB, Conners IL, Sigler L. 1980. Genera of Hyphomycetes. Canada, Alberta: The University of Alberta Press. 386 p.

Castañeda Ruiz F, Kendrick B. 1990a. Conidial fungi from Cuba: I. Univ Waterloo Biol Ser 32:1-53.

1990b. Conidial fungi from Cuba: II. Univ Waterloo Biol Ser 33:1-61.

1991. Ninety-nine conidial fungi from Cuba and three from Canada. Univ Waterloo Biol Ser 35:1132.

Ellis MB. 1971. Dematiaceous Hyphomycetes. Kew, Surrey, England: CAB Commonwealth Mycological Institute. $608 \mathrm{p}$.

- 1976. More dematiaceous Hyphomycetes. Kew, Surrey, England: CAB Commonwealth Mycological Institute. 507 p.

Goh TK, Hyde KD. 1996. Janetia curviapicis, a new species, and an emended description of the genus. Mycologia 88:1014-1021.

- - 1999. A synopsis of Trichocladium species, based on the literature. Fung Divers 2:101-118.

Goos RD, Abdullah SK, Fisher PJ, Webster J. 1985. The anamorph genus Helicodendron. Trans Br Mycol Soc 84: 423-435.

Hawksworth DL, Kirk PM, Sutton BC, Pegler DN. 1995. Ainsworth \& Bisby's dictionary of the fungi. Ed. 8. UK: CAB International. 616 p.

Ho WH, Goh TK, Hyde KD, Hodgkiss IJ. 1998. Studies of conidial anatomy and conidiogenesis in Sporoschisma nigroseptatum using light and electron microscopy. Can J Bot 76:1614-1623.

Hyde KD, Yanna, Pinnoi A, Jones EBG. 2002. Goidanichiella fusiforma sp. nov. from palm fronds in Brunei and Thailand. Fung Divers 11:119-122.

Jones EBG, Abdel-Wahab MA, Vrijmoed LLP. 2001. Tricho- 
cladium melhae sp. nov., a new tropical marine fungus. Fung Divers 7:49-52.

Kirk PM, Sutton BC. 1980. Henicospora gen. nov. (Hyphomycetes). Trans Br Mycol Soc 75:249-253.

Matsushima T. 1975. Icones microfungorum a matsushima lectorum. Kobe, Japan: Publ by author. 209 p, 415 plates.

1985. Matsushima Mycological Memoirs No. 4 Kobe, Japan: Published by author. 68 p.

Rao V, de Hoog GS. 1986. New or critical Hyphomycetes from India. Stud Mycol 28:1-84.

Sutton BC. 1980. The Coelomycetes. Fungi imperfecti with pycnidia, acervuli and stromata. Kew, Surrey, UK: Commonwealth Mycological Institute. 696 p.

Yanna, Hyde KD, Frohlich J. 1997. A new species of Appendicospora from Hong Kong. Mycoscience 38:395-397. $\longrightarrow,-$ Goh TK. 1998a. Koorchaloma novojournalis sp. nov., a new sporodochial fungus from Hong Kong. Fung Divers 1:193-197.

, $\longrightarrow$. 1998b. Staurophoma calami, a new coelomycete from Hong Kong. Sydowia 50:139-143.

- — - 1999. Endomelanconium phoenicicola sp. nov., a new coelomycete from Phoenix hanceana in Hong Kong. Fung Divers 2:199-204.

, Ho WH, Goh TK, Hyde KD. 2000a. A new species of Everhartia, associated with leaf spots of Phoenix hanceana from Hong Kong. Bot J Linn Soc 134:465-476. ,,--- - 2000b. Craspedodidymum nigroseptatum sp. nov., a new hyphomycete on palms from Brunei Darussalam. Mycol Res 104:1146-1151.

, — Hyde KD. 2002. Fungal succession on fronds of Phoenix hanceana in Hong Kong. Fung Divers 10:185-211. 